\title{
PENGARUH KARAKTERISTIK PERUSAHAAN TERHADAP PENGUNGKAPAN CORPORATE SOCIAL RESPONSIBILITY (CSR)
}

\author{
Syahrina Noormala Dewi \\ Universitas Pattimura Ambon
}

\begin{abstract}
The financial report is the information about the performance of the company and report to the stakeholders responsibility them. In general the financial report aims to provide financial information a company, both in time and in a certain period of both arranged all of a sudden in accordance with the requirements of the companies and periodically. The analysis of the data using the double linier regression as described previously obtained that the model developed in this research is worthy (fit) and successfully shows as a good model. The results of this study only gives the meaning of the variables the size of the board of commissioners and leverage that is able to explain the broad social disclosure significantly strengthened
\end{abstract}

Key words: character, Corporate, Responsibility

\section{Latar Belakang Masalah}

Laporan keuangan perusahaan dibutuhkan untuk memberikan informasi kepada pihak intern dan ekstern yang memiliki kepentingan terhadap perusahaan tersebut. Pihak intern yang memiliki kepentingan terhadap laporan keuangan tersebut adalah pemilik perusahaan dan pemimpin perusahaan, sedangkan sebagai pihak ekstern adalah para investor, kreditor/banker, pemerintah, dan masyarakat. Laporan keuangan merupakan hasil ringkasan data keuangan perusahaan yang disusun guna memberikan informasi kepada berbagai pihak yang terdiri dari neraca, laporan laba rugi, laporan modal sendiri dan laporan sumber penggunaan dana (Djarwanto 2001:5). Dalam PSAK no.1 (revisi tahun 2011) menyatakan bahwa:

Tujuan laporan keuangan adalah menetapkan dasar-dasar bagi 
penyajian laporan keuangan bertujuan umum (general purpose financial statements) yang selanjutnya disebut 'laporan keuangan' agar dapat dibandingkan baik dengan laporan keuangan periode sebelumnya maupun dengan laporan keuangan entitas lain. Pernyataan ini mengatur persyaratan bagi penyajian laporan keuangan, struktur laporan keuangan, dan persyaratan minimum isi laporan keuangan.

Dari kutipan diatas dapat disimpulkan bahwa out put dari laporan keuangan adalah informasi mengenai kinerja perusahaan dan laporan tanggung jawab kepada para stakeholder mereka. Secara umum laporan keuangan bertujuan untuk memberikan informasi keuangan suatu perusahaan, baik pada saat tertentu maupun pada periode tertentu baik disusun secara mendadak sesuai kebutuhan perusahaan maupun secara berkala.

Devina, dkk (2004) menyebutkan bahwa informasi yang diungkapkan dalam laporan keuangan dapat dikelompokan menjadi dua yaitu pengungkapan bersifat wajib (mandatory) yaitu pelaksanaannya sudah diatur oleh Undang-undang dan pengungkapan bersifat sukarela (voluntary) yaitu tidak sepenuhnya diatur oleh Undang-undang. Sedangkan menurut Guthrie dan Mathews (dalam Sembiring, 2005), salah satu jenis informasi pengungkapan sukarela yang sering diminta untuk diungkapkan perusahaan saat ini adalah informasi tentang tanggung jawab sosial perusahaan. Pengungkapan tanggung jawab sosial perusahaan muncul karena adanya tuntutan dari masyarakat dan para pengguna laporan keuangan terhadap dampak kegiatan bisnis perusahaan.

Corporate Social Responsibility (CSR) merupakan suatu konsep akuntansi yang dapat membawa perusahaan agar melaksanakan tanggung jawabnya terhadap lingkungan dan masyarakat. CSR timbul sebagai akibat dari keberadaan perusahaan-perusahaan yang aktivitasnya selain memberi banyak manfaat tetapi menimbulkan banyak dampak negatif. Dampak negatif tersebut terutama dirasakan oleh masyarakat sekitar yang berada d ekat dengan perusahaan. Corporate Social Responsibility (CSR) juga merupakan komitmen perusahaan atau dunia bisnis untuk berkontribusi 
dalam pengembangan ekonomi yang berkelanjutan dengan memperhatikan tanggung jawab sosial perusahaan dan menitikberatkan pada keseimbangan antara perhatian terhadap aspek ekonomi, sosial dan lingkungan yang disebut tripple buttom line (Suhandri M. Putri, dkk, 2007).

Corporate Social Responsibility dimaksudkan untuk mendorong dunia usaha lebih etis dalam menjalankan aktivitasnya agar tidak berpengaruh atau berdampak buruk pada masyarakat dan lingkungan hidupnya. Konsep CSR ini mulai dikenal sejak awal 1970-an, yang secara umum diartikan sebagai kumpulan kebijakan dan praktek yang berhubungan dengan stakeholder, nilai-nilai, pemenuhan ketentuan hukum, penghargaan masyarakat dan lingkungan, serta komitmen dunia usaha untuk kontribusi dalam pembangunan secara berkelanjutan. Pemikiran yang melandasi adanya Corporate Social Responsibility (Tanggung Jawab Sosial Perusahaan) ini adalah bahwa perusahaan tidak hanya memiliki tanggung jawab kepada para pemegang saham (shareholder), tetapi juga memiliki tanggung jawab kepada pihak-pihak lain yang berkepentingan (stakeholder). Pihak-pihak yang berkepentingan dalam sebuah perusahaan adalah pelanggan, pegawai, komunitas, pemilik atau investor, supplier dan juga competitor..

Di Indonesia, praktik CSR telah mendapat perhatian yang cukup besar. Hal ini dilatarbelakangi oleh berbagai kasus yang terjadi seperti penggundulan hutan, meningkatnya polusi dan limbah, buruknya kualitas dan keamanan produk, eksploitasi sumber daya alam yang berlebihan, penyalahgunaan investasi, dll. Pemilihan sampel perusahaan manufaktur oleh peneliti dikarenakan pelaksanaan CSR pada perusahaan manufaktur sudah ada sejak awal berjalan. Alasan lainnya adalah karena perusahaan manufaktur lebih banyak memberikan pengaruh/dampak terhadap lingkungan di sekitarnya akibat dari aktivitas yang dilakukan perusahaan dan memenuhi segala aspek pada tema pengungkapan CSR. Perusahaan manufaktur dipercaya membutuhkan image yang lebih baik dari masyarakat karena rentan terhadap pengaruh politik dan kritikan dari aktivis- aktivis sosial, maka diasumsikan bahwa perusahaan 
manufaktur akan memberikan pengungkapan corporate social responsibility yang lebih luas daripada p erusahaan non manufaktur.

Suatu perusahaan memang tidak dapat dipisahkan dari tanggung jawabnya terhadap sosial dan lingkungan. Banyak perusahaan yang seakan berlomba meng-expose diri dalam kegiatan yang berorientiasi sosial, seperti PT. Unilever Indonesia dengan program "Lifebouy Hand Washing Campaign dan "Rinso, Bersih Itu Baik" dan AQUA dengan program "1=10 Liter", serta banyak lagi program sosial yang memiliki program CSR yang beragam. Sebagai contoh, PT Indonesia Asahan Aluminium (Inalum) dengan pemegang saham dari Jepang, dalam hal ini pemerintah bersikeras untuk mengambil alih Inalum namun ada dua ganjalan dalam akusisi tersebut yaitu berkaitan dengan kewajiban corporate social responsibility seperti belum dibayarkan kewajibankewajiban ke beberapa kabupaten berupa 10.000 beasiswa ke warga sekitar dan gaji pada karyawan. Dari kasus tersebut terlihat masih ada perusahaan manufaktur yang belum peduli pada kesejahteraan masyarakat.

Oleh karean itu, dikeluarkannya beberapa peraturan pemerintah yang mendorong praktik $\mathrm{d}$ an pengungkapan CSR di Indonesia. Salah satunya Undang-Undang Perseroan Terbatas Nomor 40 tahun 2007, pasal 66 dan 74. Pasal 66 ayat (2) bagian c berisi bahwa selain menyampaikan laporan keuangan, perusahaan juga diwajibkan melaporkan pelaksanaan tanggungjawab sosial dan lingkungan. Pada Pasal 74 (ayat 1) Undang-undang Perseroan Terbatas berisi tentang perseroan yang menjalankan kegiatan usahanya di bidang dan/ atau berkaitan dengan segala sumber daya alam wajib melaksanakan tanggung jawab sosial dan lingkungan.

Dampak sosial perusahaan tergantung pada jenis atau karateristik perusaahaan. Karateristik operasi perusahaan yang menghasilkan dampak sosial yang tinggi akan menuntut pemenuhan tanggungjawab sosial yang lebih tinggi pula. Dalam hal ini salah satu karateristik perusahaan yaitu ukuran dewan komisaris, profitabilitas dan leverage. 
Beberapa penelitian mengenai karateristik perusahaan dan CSR telah dilakukan oleh beberapa peneliti terdahulu, salah satunya dilakukan oleh melakukan penelitian Jurica Lucyanda dan Lady GraciaPrilia Siagian (2012). Jurica Lucyanda dan Lady GraciaPrilia Siagian (2012) melakukan penelitian CSR menggunakan variabel independen yang terdiri dari Ukuran perusahaan, profitabilitas, Profil, Laba per saham, dan Kepedulian lingkungan, Leverage, Dewan komisaris, Umur perusahaan, Kepemilikan manajemen, dan Peluang pertumbuhan. Dari penelitian Jurica Lucyanda ditemukan perbedaan hasil antara penelitian Arief Sabeni dan Norhadi (2002), Sembiring (2005), Sitepu dan Hasan (2008) dan penelitian Sylvia Veronica (2009) baik yang berpengaruh hubungan positif maupun yang berpengaruh kehubungan negatif. Perbedaan penelitian ini dengan penelitian Jurica Lucyanda dan Lady GraciaPrilia Siagian (2012) dan terletak pada sampel dan tahun penelitian, yaitu pada sektor manufaktur yang terdaftar di BEI tahun 2009-2011 sedangka Jurica Lucyanda dan Lady GraciaPrilia Siagian (2012) menggunakan sampel perusahaan-perusahaan go public yang terdaftar di BEJ untuk tahun 2007-2009.

Berdasarkan latar belakang masalah yang diuraikan tersebut, rumusan masalah yang akan diteliti dalam penelitian ini adalah "Pengaruh Karateristik Perusahaan Terhadap Corporate Social Responsiility (CSR)". Dari judul penelitian tersebut diperoleh rumusan masalah sebagai berikut :

1. Apakah ukuran dewan komisaris berpengaruh terhadap pengungkapan CSR?

2. Apakah profitabilitas berpengaruh terhadap pengungkapan CSR?

3. Apakah leverage berpengaruh terhadap pengungkapan CSR?

\section{Kerangka Teoritis Dan Pengembangan Hipotesis}

Ukuran Dewan Komisaris Terhadap Pengungkapan CSR

Menurut Fama dan Jensen (1983), ukuran dewan komisaris merupakan mekanisme pengendalian intern 
tertinggi, yang bertanggungjawab untuk memonitor tindakan manajemen puncak. Dewan komisaris terdiri dari inside dan outside director yang akan memiliki akses informasi khusus yang berharga dan sangat membatu dewan komisaris serta menjadikannya sebagai alat efektif dalam keputusan pengendalian.

Untuk mewujudkan akuntabilitas perusahaan, dewan komisaris dapat memberikan pengaruh yang cukup kuat untuk menekan manajemen mengungkapkan informasi sosial yang lebih luas, sehingga perusahaan yang memiliki ukuran dewan komisaris yang lebih besar akan lebih banyak mengungkapkan informasi sosial. Teori agensi (agency theory) telah digunakan secara luas dalam penelitian tentang dewan komisaris.

Penelitian yang menunjukkan adanya hubungan yang positif antara ukuran dewan komisaris dengan tingkat pengungkapan informasi sosial perusahaan antara lain adalah penelitian yang dilakukan oleh Sembiring (2005). Penelitian tersebut menunjukkan bahwa ada hubungan positif antara ukuran dewan komisaris dengan tingkat pengungkapan CSR. Penelitian lain oleh Conyon dan Peck (1998) dalam Elinda et,al., juga menyebutkan bahwa ukuran dewan komisaris berpengaruh terhadap corporate social responsibilty. Berdasarkan uraian di atas, maka hipotesis yang diajukan dalam penelitian ini adalah sebagai berikut:

H1 : Ukuran dewan komisaris berpengaruh positif terhadap pengungkapan CSR.

\section{Profitabilitas Terhadap Pengungkapan CSR}

Profitabilitas merupakan kemampuan perusahaan untuk menghasilkan laba dalam upaya meningkatkan nilai pemegang saham. Berdasarkan teori legitimasi (legitimacy theory), profitabilitas merupakan faktor yang membuat manajemenmenjadibebas danfleksibeluntukmengungkapkan pertanggung jawaban sosial kepada pemegang saham, sehingga semakin tinggi tingkat profitabilitas perusahaan maka semakin besar pengungkapan informasi sosial (Heinze dan Gray, et al. 1976). Dengan demikian bagi investor jangka panjang akan sangat berkepentingan dengan analisa profitabilitasini. Meskipun, dengan berjalannya waktu menuai 
protes banyak kalangan, yang tidak relevan menjadi dasar strategi operasional perusahaan. Mana mungkin perusahaan tanpa didukung oleh kemampuan mencetak keuntungan yang memadai mampu menjamin dan mempertahankan going concern". Peningkatan kesejahteraan personil dalam perusahaan, meningkatkan tingkat kesejahteraan pemilik (shareholder), yang hal itu bisa dilakukan manakala didukung kemampuan menciptakan keuntungan (profit) perusahaan.

Hubungan antara pengungkapan tanggung jawab sosial perusahaan dan profitabilitas perusahaan telah didalilkan untuk mencerminkan pandangan bahwa reaksi sosial memerlukangaya managerial yang sama dengan gaya manajerial yang diperlukan untuk membuat suatu perusahaan memperoleh keuntunagn (Bowman dan Haire, 1976). Mulyadi dan Anwar (2011) melakukan penelitianmengenai investor's serception on corporate responsibility of Indonesian listed companies. Hasil menunjukkan tanggung jawab sosial perusahaan tidak berpengaruh signifikan terhadap dampak stock's return. Sehingga tidak mendukung hubungan profitabilitas dengan pengungkapan tanggung jawab sosial perusahaan. Sedangkan, profitabilitas menurut Saidi (2004) adalah kemampuan perusahaan dalam memperoleh laba sehingga dapat menggambarkan keberadaan perusahaan terhadap pengungkapan CSR. Berdasarkan uraian di atas, maka hipotesis yang diajukan dalam penelitian ini adalah sebagai berikut:

\section{H2: Profitabilitas berpengaruh positif terhadap pengungkapan} CSR.

\section{Leverage Terhadap Pengungkapan CSR}

Leverage merupakan alat untuk mengukur seberapa besar perusahaan tergantung pada kreditur dalam membiayai aset perusahaan. Leverage mencerminkan tingkat risiko keuangan perusahaan (Sembiring, 2005). Selain itu leverage merupakan proporsi total hutang terhadap rata-rata ekuitas pemegang saham. Rasio tersebut digunakan untuk memberikan gambaran mengenai struktur modal yang dimiliki perusahaan, sehingga dapat dilihat tingkat resiko tak tertagihnya suatu utang. Menurut Belkaoui dan Karprik (1989) keputusan untuk mengungkapkan informasi sosial akan meningkatkan suatu pengeluaran untuk pengungkapan 
yang menurunkan pendapatan.

Sesuai dengan teori agensi (agency theory), manajemen perusahaan dengan tingkat leverage yang tinggi akan mengurangi pengungkapan tanggung jawab sosial yang dibuatnya agar tidak menjadi sorotan dari para debtholders. Hasil menunjukan leverage berpengaruh negatif terhadap tanggung jawab sosial perusahaan. Sedangkan penelitian Naser, et al menyatakan bahwa leverage berpengaruh signifikan terhadap pengungkapan CSR. Berdasarkan uraian di atas, maka hipotesis yang diajukan dalam penelitian ini adalah sebagai berikut:

\section{H3 : Leverage berpengaruh positif terhadap pengungkapan CSR}

\section{Metode Penelitian}

Populasi penelitian ini adalah perusahaan manufaktur yang telah terdaftar di Bursa Efek Indonesia (BEI) pada tahun 2009-2011. Sampel diambil dengan metode purposive sampling, yaitu teknik pengambilan sampel dengan kriteria tertentu antara lain perusahaan manufaktur yang terdftar di BEI dari tahun 2009-2011 melalui situs Bursa Efek Indonesia (www.idx.co.id) serta mengungkapkan laporan tanggung jawab sosial melalui laporan tahunannya.

Metode pengumpulan data pada penelitian ini adalah metode dokumentasi, yaitu penggunaan data yang berasal dari dokumen-dokumen yang sudah ada. Pengumpulan data dilakukan dengan dengan melihat data-data yang diperlukan, mencatat, dan menganalisis annual report perusahaan tahun 2009-2011.

Variabel dependen dalam penelitian ini adalah corporate social responsibility. Darwin (2004) dalam Rawi dan Munawar (2010) mendefinisikan Corporate Social Responsibility sebagai mekanisme bagi suatu organisasi untuk secara sukarela mengintegrasikan perhatian terhadap lingkungan dan sosial terhadap operasinya dan interaksinya dengan stakeholders, yang melebihi tanggung jawab organisasi di bidang hukum. Pengukuran variabel ini dilakukan dengan cara mengamati ada atau tidaknya suatu item informasi yang ditentukan dalam laporan tahunan, apabila item informasi tidak ada dalam laporan keuangan maka diberi skor 0 , dan jika item 
informasi yang ditentukan ada dalam laporan keuangan tahunan maka diberi skor 1 .

Dalam hal ini, metode analisis yang digunakan adalah metode analisis isi (content analysis) dimana peneliti akan mengamati ada tidaknya item informasi yang diungkapkan dalam annual report. Itemitem tersebut didasarkan pada Key Succes Factors for Social Performance yang berisi 78 indiktor pengukuran corporate social responsibility (Sembiring, 2005). Ketujuh kategori tersebut dijabarkan ke dalam 78 item pengungkapan yang telah disesuaikan dengan kondisi yang ada di Indonesia sesuai dengan peraturan yang berlaku.

Variabel dependen dalam penelitian ini adalah ukuran dewan komisaris, profitabilitas dan leverage. Adapun definisi operasional dan pengukuran masing-masing variabel dijelaskan sebagai berikut:

a. Ukuran dewan komisaris

Variabel ukuran dewan komisaris merupakan anggota dewan direksi yang memiliki pengaruh terhadap kemampuan untuk bertindak independen semata-mata demi keuntungan perusahaan (Komite nasional Kebijakan Governance, 2004). Ukuran dewan komisaris diukur dengan jumlah dewan komisaris dalam perusahaan.

b. Profitabilitas

Profitabilitas menurut Saidi (2004) adalah kemampuan perusahaan dalam memperoleh laba dari kegiatan operasinya. Profitabilitas diukur dengan laba bersih sesudah pajak dibagi dengan total aktiva.

c. Leverage

Leverage dapat diartikan sebagai tingkat ketergantungan perusahaan terhadap hutang dalam membiayai kegiatan operasinya, dengan demikian leverage juga mencerminkan tingkat resiko keuangan perusahaan, Sembiring (2005). Leverage diukur dengan total kewajiban dibagi dengan ekuitas pemegang saham.

Analisis regresi berganda digunakan untuk memprediksi pengaruh lebih dari satu variabel bebas terhadap satu variabel tergantung, baik secara parsial maupun simultan. Mengingat penelitian ini menggunakan 
Pengaruh Karakteristik Perusahaan terhadap Pengungkapan ....

empat variabel bebas, maka persamaan regresinya sebagai berikut :

$$
\mathrm{CSR} \text { disk }=0+\beta 2 \mathrm{UDK}+\beta 3 \text { Prof }+\beta 4 \mathrm{Lev}
$$

Keterangan:

CSRD : Indeks Pengungkapan CSR perusahaan

UDK : Proporsi Ukuran Dewan Komisaris

Prof : Profitabilitas

Lev : Leverage

$\square i \quad:$ error term

\section{Hasil Penelitian Dan Pembahasan}

\subsection{Deskriptif Objek Penelitian}

Populasi yang digunakan di dalam penelitian ini adalah perusahaan-perusahaan manufaktur yang terdaftar di BEI (Bursa Efek Indonesia) untuk tahun 2009 sampai dengan tahun 2011. Dengan mengunakan metode pengabungan data selama pengamatan 3 tahun tersebut dipeorleh sebanyak 30 x 3 periode atau diperoleh sebanyak 90 data pengamatan. Selanjutnya sejumlah data tersebut digunakan untuk analisis data dan pengujian hipotesis.

Variabel Ukuran Dewan Komisaris (UDK) dalam penelitian ini menunjukkkan nilai modus sebesar 5. Hal ini menunjukkan bahwa bagian terbesar dari perusahaan sampel memiliki dewan komisaris sebanyak 5 orang. Ukuran dewan komisaris terkecil sebanyak 2 orang dan ukuran dewan komisaris terbanyak adalah 10 orang. Keberadaan dewan komisaris memiliki peran dalam mengawasi kebijakan manajemen.

Statistik deskriptifdarivariable profitabilitas perusahaan yang diukur dengan menggunakan Return on asset (ROA) menunjukkan rata-rata sebesar 9,998\%. Nilai ROA tersebut menunjukkan adanya kemampuan perusahaan dalam menghasilkan laba hingga 9,998\% disbanding total asset yang dimiliki perusahaan. Nilai minimal dari profitabilitas adalah sebesar $-7,00 \%$ dan nilai maksimal dari profitabilitas adalah sebesar $41,62 \%$.

Statistik deskriptif dari variable leverage perusahaan yang diukur dengan menggunakan debt to equity ratio 
menunjukkan rata-rata sebesar 1,786. Nilai everage tersebut menunjukkan bahwa perusahaan memiliki hutang yang cenderunh lebih besar dari modal sendiri yang dimiliki perusahaan. Nilai minimal dari Leverage adalah sebesar 0,135 dan nilai maksimal dari rasio leverage adalah sebesar 27,977.

Penelitian ini menggunakan tema pengungkapan sosial yang secara keseluruhan terdiri dari 78 item pada 7aspek yang diusung dalam CSR. Indeks pengungkapan CSR yang diukur dengan 78 item pengungkapan diperoleh sebesar 0,233 atau $23,3 \%$. Hal ini berarti bahwa dalam satu periode 2009 hingga 2011dalam annual report, perusahaan sampel mengungkapkan sebanyak $23,3 \%$ pengungkapan sosial yang dilakukan perusahaan. Indeks pengungkapan CSR terkecil adalah sebesar 0,013 dan indeks pengungkapan terbesar adalah sebesar 0,449.

\subsection{Analisis Data}

Penelitian ini menggunakan model regresi linier yaitu model yang menguji pengaruh ukuran dewan komisaris, profitabilitas dan leverage terhadap pengungkapan CSR. Model regresi yang baik disyaratkan harus memenuhi tidak adanya masalah asumsi klasik. Uji asumsi klasik dari masingmasing model adalah sebagai berikut :

\subsubsection{Hasil Uji Asumsi Klasik}

Untuk mendapatkan model yang tepat, maka regresi linier berganda tersebut harus bebas dari masalah asumsi klasik. Untuk itu akan diuji terlebih dahulu mengenai tidak adanya penyimpangan terhadap asumsi klasik yang terdiri dari uji normalitas, multikolinieritas, heteroskedastisitas dan autokorelasi.

\section{Normalitas}

Hasil penelitian menunjukkan bahwa variabel Profit dan Lev memiliki data-data ekstrim. Hal ini ditunjukkan dengan nilai z-score pada variabel-variabel tersebut yang lebih besar dari +3. Untuk itu dapat dilakukan dengan mengeluarkan data-data outlier. Hasil penelitian menunjukkan semua variabel tidak ada lagi yang memiliki data-data ekstrim. Hal ini ditunjukkan dengan nilai z-score pada variabel-variabel tersebut yang lebih besar dari kecil dari +3 .

Hasil pengujian normalitas pada pengujian terhadap 79 
data atau dengan mengeluarkan 11 data outlier menunjukkan bahwa model regresi setelah transformasi data logaritma memiliki nilai residual yang berdistribusi normal. Hal ini ditunjukkan dengan nilai signifikansi pengujian Kolmogorov Smirnov tersebut lebih besar dari 0,05, sedangkan variabel lainnya tidak berdistribusi normal. Grafik PP Plot juga menunjukkan kecilnya penyimpangan yang tidak jauh dari garis diagonal.

\section{Multikolinier}

Pengujian multikolinieritas dalam model regresi dilakukan dengan melihat nilai Tolerance VIF dari output regresi. Nilai VIF yang lebih besar dari 10 atau Tolerance yang lebih kecil dari 0,1 menunjukkan adanya gejala multikolinieritas dalam model regresi. Hasil pengujian menunjukkan bahwa tidak ada nilai VIF dari variable yang memiliki nilai lebih dari angka 10. Dengan demikian model regresi tersebut tidak masih memiliki masalah multikolinier. Dengan demikian model regresi tersebut sudah tidak memiliki masalah multikolinier.

\section{Heteroskedastisitas}

Pengujian heteroskedastisitas dilakukan dengan menggunakan Scatterplot. Pola scatter plot yang tidak membentuk garis atau bergelombang menunjukkan tidak adanya masalah heteroskedastisita. Pola Scatter Plot menunjukkan data yang menyebar di bidang $X$ dan $Y$. Dengan demikian maka dapa disimpulkan tidak terdapat masalah heteroskerdastisitas pada model regresi. Hal ini memperkuat dugaan tidak adanya masalah heteroskedastisitas dalam model regresi.

\section{Autokorelasi}

Pengujian autokorelasi dilakukan dengan menggunakan uji Durbin Watson. Nilai Durbin Watson yang berada diantara nilai du dan 4 - du menunjukkan model yang tidak terkena masalah autokorelasi. Nilai DW yang diperoleh adalah sebesar 1,933. Nilai tabel du untuk $\mathrm{k}=3$ dan data sebanyak 79 diperoleh sebesar 1,74. Dengan demikian nilai DW $=1,933$ berada diantara 1,74 dan $4-\mathrm{du}=2,26$. Hal ini berarti tidak ada masalah autokorelasi pada model regresi. 


\subsubsection{Model Regresi}

Perhitungan analisis regresi ini menggunakan bantuan program SPSS versi 16. Persamaan regresi dalam penelitian ini diperoleh sebagai berikut :

$$
\text { CSR }=0,136+0,010 \text { UDK- 0,0002 PROF + 0,055 LEV }
$$

Hasil persamaan tersebut menunjukkan bahwa koefisien positif diperoleh pada variable ukuran dewan komisaris dan leverage sedangkan koefisien negative pada variable profitabilitas.

\subsubsection{Overal Model F}

Hasil uji overall model terlihat bahwa nilai $\mathrm{F}=4,030$ dengan probabilitas sebesar $0,010<0,05$. Nilai probabilitas pengujian yang lebih besar dari a $=0,05$ menunjukkan bahwa CSR dapat dijelaskan oleh ukuran dewan komisaris, profitabilitas dan leverage.

\subsubsection{Koefisien Determinasi}

Nilai Koefisien Determinasi (adjusted $R^{2}$ ) sebesar 0,104 yang berarti bahwa hanya $10,4 \%$ saja CSR dalam penelitian ini dapat dijelaskan oleh variabel ukuran dewan komisaris, profitabilitas dan leverage, sedangkan $89,6 \%$ CSR dapat dijelaskan oleh variabel lainnya.

\subsubsection{Pengujian Hipotesis}

Untuk menentukan pengaruh masing - masing variabel bebas terhadap variabel tergantung di gunakan uji t. Dari hasil estimasi regresi pada lampiran diketahui nilai $t$ hitung sebagai berikut :

\section{Pengaruh Ukuran Dewan Komisaris terhadap CSR}

Berdasarkan hasil perhitungan dengan menggunakan program SPSS diperoleh hasil uji pengaruh Ukuran Dewan Komisaris terhadap CSR diperoleh nilai t sebesar 2,049 dengan nilai probabilitas sebesar 0,044 yang menunjukkan nilai yang lebih kecil dari 0,05. Dengan demikian dapat disimpulkan bahwa Ho ditolak atau menerima $\mathrm{H} 1$ yang artinya variabel Ukuran Dewan Komisaris berpengaruh signifikan terhadap CSR. Arah koefisien positif berarti bahwa peningkatan ukuran dewan komisaris akan meningkatkan CSR.

\section{Pengaruh Variabel Profitabilitas terhadap CSR}

Berdasarkan hasil perhitungan dengan menggunakan program SPSS diperoleh hasil uji pengaruh profitabilitas 
terhadap CSR diperoleh nilai t sebesar -0,135 dengan nilai probabilitas sebesar 0,893 yang menunjukkan nilai yang lebih besar dari 0,05. Dengan demikian dapat disimpulkan bahwa Ho diterima yang artinya variabel ROA tidak berpengaruh signifikan terhadap CSR.

\section{Pengaruh Variabel Leverage terhadap CSR}

Berdasarkan hasil perhitungan dengan menggunakan program SPSS diperoleh hasil uji pengaruh leverage terhadap CSR diperoleh nilai $t$ sebesar 2,700 dengan nilai probabilitas sebesar 0,009 yang menunjukkan nilai yang lebih kecil dari 0,05. Dengan demikian dapat disimpulkan bahwa Ho ditolak atau menerima $\mathrm{H} 3$ yang artinya variabel Leverage berpengaruh signifikan terhadap CSR. Arah koefisien positif berarti bahwa peningkatan Leverage akan meningkatkan CSR.

\subsection{Pembahasan}

1. Pengaruh Ukuran Dewan Komisaris terhadap CSR

Penelitian ini mendapatkan bahwa Ukuran dewan komisaris memiliki pengaruh positif signifikan terhadap pengungkapan sosial (CSR). Hal ini berarti bahwa semakin besar jumlah dewan komisaris yang dimiliki oleh perusahaan, akan semakin luas pengungkapan sosial yang dilakukan oleh perusahaan.

Hal ini menunjukkan bahwa peran komisaris dalam pengawasan terhadap manajer cukup mambantu kebijakan manajer dalam mengungkapkan aktivitas sosial perusahaan dalam laporan annual report. Hal ini nampaknya dapat dikarenakan bahwa komisaris dapat melihat peran CSR sebagai informasi yang dapat menunjang kepercayaan publik kepada perusahaan. Dengan pertimbangan tersebut dewan komisaris dapat menyarankan direksi untuk mengungkapkan laporan CSR secara lebih luas.

2. Pengaruh Profitabilitas terhadap CSR

Hasil pengujian menunjukkan bahwa profitabilitas tidak berpengaruh signifikan terhadap CSR. Alasan mendasar atas tidak adanya pengaruh yang signifikan dari variable profitabilitas terhadap pengungkapan sosial CSR adalah karena pengungapan aktivitas sosial oleh perusahaan merupakan pengngkapan sukarela, sehingga manajer nampaknya 
memiliki pertimbangan bahwa dalam kondisi perolehan profitabilitas perusahaan yang baik, maka perusahaan tidak perlu lagu menggunakan pengungkapan social untuk mendapatkan legitimasi dari para investor.

Hal ini menunjukkan adanya kecenderungan bahwa dengan diperolehnya laba yang bagus, maka manajer berasumsi sudah mampu mendapatkan penilaian positif dari investor sehingga manajer tidak perlu mengungkapkan CSR yang lebih luas.

3. Pengaruh Leverage terhadap CSR

Hasil pengujian menunjukkan leverage berpengaruh signifikan terhadap CSR dengan arah positif. Hal ini berarti bahwa perusahaan dengan leverage yang lebih besar akan mengungkapkan CSR yang lebih luas.

Alasan mendasar atas signifikannya pengaruh leverage terhadap pengungkapan sosial adalah karena aktivitas sosial perusahaan kemungkinan lebih merupakan aktivitas perusahaan yang dapat digunakan oleh manajer untuk mendapatkan legitimasi dari investor. Dalam hal ini manajer nampaknya akan menggunakan kondisi laporan CSR untuk mendapatkan legitimasi bahwa manajer dapat melakukan aktivitas yang bermanfaat bagi perusahaan. Hal ini memberikan satu fenomena bahwa CSR dapat menjadi satu bentuk alasan atau informasi yang diberikan oleh perusahaan.

\section{Kesimpulan Dan Keterbatasan}

\subsection{Kesimpulan}

Berdasarkan hasil analisis data dengan menggunakan regresi linier berganda sebagaimana dijelaskan sebelumnya didapatkan bahwa model yang dikembangkan dalam penelitian ini adalah layak (fit) dan berhasil menunjukkan sebagai model yang baik. Hasil penelitian ini hanya memberikan yang bermakna dari variabel ukuran dewan komisaris dan leverage yang mampu menjelaskan luas pengungkapan sosial secara signifkan. Berikut adalah pembahasan tentang hubungan antara variabel-variabel yang dihipotesiskan dalam penelitian ini.

1. Ukuran dewan komisaris berp engaruh positif terhadap luas pengungkapan sosial dalam laporan tahunan perusahaan. Perusahaan yang memiliki dewan 
komisaris yang lebih besar akan cenderung memberikan pengungkapan sosial yang lebih luas.

2. Profitabilitas Perusahaan tidak berpengaruh signifikan terhadap luas pengungkapan sosial dalam laporan tahunan perusahaan.

3. Leverage berpengaruh positif terhadap luas pengungkapan sosial dalam laporan tahunan perusahaan. Perusahaan yang memiliki leverage yang lebih besar akan cenderung memberikan pengungkapan sosial yang lebih luas.

\subsection{Keterbatasan Penelitian}

Keterbataan dalam penelitian ini dapat diungkapkan sebagai berikut :

1. Sulit mencari laporan keuangan perusahaan yang lengkap sehingga penelitian ini mengsumsikan bahwa data perusahaan yang tidak ada diasumsikan tidak mengeluarkan pengungkapan sosial. Hal ini karena tidak semua perusahaan mengungkapkan annual report mereka di website BEI. Dalam hal ini sumber data yang digunakan oleh peneliti hanya berasal dari BEI.

2. Subyektifitas penilai masih nampak, karena laporan pengungkapan sosial tidak disajikan secara eksplisit sehingga masih memerlukan interpretasi penilai. 


\section{DAFTAR PUSTAKA}

Anggraini, Fr. RR. (2006). “Pengungkapan Informasi Sosial dan Faktor-Faktor yang Mempengaruhi Pengungkapan Informasi Sosial d alam Laporan Keuangan Tahunan (Studi Empiris pada Perusahaan-Perusahaan yang Terdaftar p ada Bursa Efek Jakarta)". Simposium Nasional A kuntansi 9. Padang, 23-26 Agustus.

Arifin Sabeni (2002), “An Empyrical Analysis of The Relation Between The Board of Director's Composition an the level of Voluntary Disclosure", Prooceedings For The Fifth Indonesian Conference On Accounting, No. 5 pp. 46-57

Arifin, 2005. Peran Akuntansi Dalam Menegakakn Prinsip Good Corporate Governance pada Perusahaan di Indonesi. Seamarang: Universitas Dipenogoro.

Belkaoui, A.R. and Karpik, P.G. (1989), "Determinants of the corporate decision to disclose social information", Accounting, Auditing and Accountability Journal, Vol. 2 No.1, pp. $36-51$.

Bowen, Howard R., Social Responsibilities of The Businessman, New York: Harper \& Row, 1953.

Chariri,A dan Ghozali. (2007). Teori Akuntansi. Edisi 3. Semarang: BP Universitas Diponegoro.

Cowen, S.S., Ferreri, L.B. and Parker, L.D. (1987), "The impact of corporate characteristics on social responsibility disclosure: a typology and frequency-based analysis", Accounting, Organizations and Society, Vol. 12 No. 2, pp. $111-22$.

Darwin, Ali. 2004. "Penerapan Sustainability Reporting di Indonesia". Konvensi 
Pengaruh Karakteristik Perusahaan terhadap Pengungkapan ....

Nasional Akuntansi V. Yogyakarta, 13-15 Desember.

Elinda dan Nazli. (2012). “Corporate Social Responsibility Dan Corporate Governance in Malaysian GovernmentLinked Companies". Accounting Journals Emerald, Vol 12, Iss: 3 pp 2-2.

Fama, Eugene F. 1983. Agency Problems and the Theory of the Firm. Journal of Political Economy. 88, No.2 (April), hal. 288-307.

Forum of Corporate Governance in Indonesia. 2003. Corporate Governance: Tantangan dan Kesempatan bagi Komunitas Bisnis Indonesia. Jakarta: Prentice Hall.

Ghozali, I. Aplikasi SPSS Cetakan IV (2009). Semarang: BP Universitas Diponegoro.

Gray, R, Owen, D. and Maunders, K. (1987), “Corporate Social Reporting: Accounting and Accountability", PrenticeHall, London.

Guthrie J. and Mathews, M.R. (1985), "Corporate social accounting in Australasia",Research in Corporate Social Performance and Policy, pp. 251 - 277.

Hackston, David and Markus J. Milne. 1996. Some Determinants of Social and Environmental Disclosure in New Zealand Companies. Accounting, Auditing and Accountability Journal. Vol. 9, No. 1, p. 77-108.

Ikatan Akuntansi Indonesia. 2007. Standar Akuntansi Keuangan. Jakarta: Salemba Empat.

Jensen, Michael C. dan W.H. Meckling.(1976). Theory of The Firm: Managerial Behavior, Agency Cost and Ownership Structure. Journal of Financial Economics, Vol 3, No. 4: 305-360. 
Komite Nasional Kebijakan Governance (KNKG). 2006. Pedoman Umum Good Corporate Governance di Indonesia. Jakarta.

Maignan, I and Ferrell, O. C. 2004, Corporate Social Responsibility and Marketing: an Integrative Framework, Journal of The Academy of Marketing Science, Vol. 32, No. 1, pp. $3-20$.

Mulyadi. 2002. Auditing: Jilid 1 Edisi Enam. Jakarta: Salemba Empat

Murwaningsari, E., (2009). "Hubungan Corporate Governance, Corporate Social Responsibilities dan Corporate Financial Performance dalam Satu Continuum". Jurnal Akuntansi dan Keuangan, Vol.11 No.3, pp 30-41.

Rawi dan Munawar. (2011). “Kepemilikan Manajemen, Kepemilikan Institusi, Leverage Dan Corporate Social Responsibility". Journal of Accounting. http://www. ssrn.com. Diakses tanggal 22/08/2012. 10.43.

Ristyaningrum, Arin. 2009. "Pengaruh Karateristik Dewan Komisaris, Komite Audit, dan Struktur Kepemilikan terhadap Manajemen Laba pada Perusahaan Manufaktur". Skripsi Tidak Dipublikasikan. Universitas Diponegoro.

Robbins, S.P. "Essentials of Organization Behavior". Edisi 12, Buku 1. Jakarta: Salemba Empat.

Sari dan Kholisoh (2009). "Pengaruh Karateristik Perusahaan Terhadap Corporate Social Responsibility Disclosure Pada Perusahaan Manufaktur". Journal of Accounting. http://www.ssrn.com. Diakses tanggal 22/08/2012. 10.38 .

Saidi, Faktor-Faktor Yang Mempengaruhi Struktur Modal pada Perusahaan Manufaktur Go Public Di BEJ Tahun 19972002, Jurnal Bisnis dan Ekonomi, Vol 11, No.1, Maret, hal 44-58. 
Pengaruh Karakteristik Perusahaan terhadap Pengungkapan ....

Schermerhorn, J.R. (1993). "Management for Productivity". New York.

Scott, William R. (2000), Financial Accounting Theory, 2nd edition, Prentice-Hall Canada Inc., Scarborough, Ontario.

Sekaran, Uma. (2006). "Research Method for Business, Metododologi Penelitian untuk Bisnis". Edisi 4,. Buku 1 dan 2. Terjemahan Kwan Men Yon. Jakarta: Salemba Empat.

Sembiring, Eddy Rismanda. 2003. Kinerja Keuangan, Political Visibility, Ketergantungan pada Hutang dan Pengungkapan Tanggung Jawab Sosial Perusahaan. Simposium Nasional Akuntansi VI, Surabaya.

Sembiring, Eddy Rismanda. 2005. Karakteristik Perusahaan dan Pengungkapan Tanggung Jawab So sial : Studi Empiris pada Perusahaan yang Tercatat di Bursa Efek Jakarta. Simposium Nasional Akuntansi VIII, Solo.

Sembiring, Eddy Rismanda. 2007. "Pengaruh CSR Disclousure Terhadap Earning Response Coeficient". Simposium Nasional Akuntansi X. Makasar.

Sitepu, A.C. (2009). "Faktor-faktor Yang Mempengaruhi Pengungkapan Informasi Sosial Dalam Laporan Tahunan Pada Perusahaan Manufaktur Yang Terdaftar di Bursa Efek Jakarta". Journal of Accounting. http://www.ssrn. com. Diakses tanggal 22/08/2012. 10.39.

Sylvia Veronica N.P. Siregar dan Siddharta Utama, Pengaruh Struktur Kepemilikan, Ukuran Perusahaan, dan Praktek Corporate Governance Terhadap Pengelolaan Laba (Earnings Management) Simposium Nasional Akuntansi VIII, IAI, 2005

Sudarmadji, Ardi Murdoko, Lana Sularto, 2007. Pengaruh Ukuram Perusahaan, Profitabilitas, Leverage dan Tipe Kepemilikan Perusahaan Terhadap Luas Voluntary Disclousure Lporan 
Keuangan Tahunan. Proceeding PESAT. Vol.2 : 53-61.

Suharto, edi. 2006. Pekerjaan Sosial Industri, CSR dan Comdev.

Suwardjono, (2005). Teori Akuntansi Perekayasaan Pelaporan Keuangan, Edisi Ketiga, BPFE, Yogyakarta.

Solihin, I. Corporate Social Responsibility From Charity To Sustanbility (2009). Jakarta: Salemba Empat.

Undang-Undang Nomor 25 Tahun 2007 tentang Penanaman Modal.

Undang-Undang Nomor 40 tahun 2007 tentang Perseroan Terbatas.

Untung, B.H. Corporate Social Responsibility (2006). Jakarta: BP Sinar Grafika.

Wallace, R.S., Naser, K. and Mora, A. (1994), “The Relationship between the comprehensiveness of corporate annual reports and firm characteristics in Spain", Accounting and Business Research, Vol. 25 No. 97, pp. 41 - 53.

Widiastuti, Harjanti, "Pengaruh Luas Ungkapan Sukarela dalam Laporan Tahunan terhadap Earning Response Coefficient (ERC)", Simposium Nasional Akuntansi 5, Semarang, 5-6 September 2002

www.idx.co.id

www.google.co.id

www.media.csrindonesia.co.id 
Pengaruh Karakteristik Perusahaan terhadap Pengungkapan ....

Tabel 4.1

Deskripsi variabel penelitian

\begin{tabular}{|l|l|l|l|l|l|}
\hline & & UDK & PROFIT & LEV & CSR \\
\hline \multirow{2}{*}{ V } & 90 & 90 & 90 & 90 \\
\cline { 2 - 6 } & Malid & 0 & 0 & 0 & 0 \\
\hline Mean & 5.167 & 9.998 & 1.786 & 0.233 \\
\hline Mode & 5.000 & $-7.000^{\mathrm{a}}$ & $0.270^{\mathrm{a}}$ & 0.256 \\
\hline Std. Deviation & 2.095 & 9.672 & 3.776 & 0.095 \\
\hline Minimum & 2.000 & -7.000 & 0.135 & 0.013 \\
\hline Maximum & 10.000 & 41.620 & 27.977 & 0.449 \\
\hline \multicolumn{4}{|l|}{ a. Multiple modes exist. The smallest value is shown } & \\
\hline
\end{tabular}

Tabel 4.2

Identifikasi outlier Variabel

\begin{tabular}{|l|l|l|l|l|l|}
\hline & $\mathrm{N}$ & Min & Max & Mean & $\begin{array}{l}\text { Std. } \\
\text { Deviation }\end{array}$ \\
\hline Zscore(UDK) & 90 & -1.51177 & 2.30744 & .0000000 & 1.00000000 \\
\hline Zscore(PROFIT) & 90 & -1.75735 & 3.26935 & .0000000 & 1.00000000 \\
\hline Zscore(LEV) & 90 & -.43719 & 6.93535 & .0000000 & 1.00000000 \\
\hline Zscore(CSR) & 90 & -2.31945 & 2.27890 & .0000000 & 1.00000000 \\
\hline Valid N (listwise) & 90 & & & & \\
\hline
\end{tabular}

Tabel 4.3

Identifikasi outlier Variabel setelah mengeluarkan outlier

\begin{tabular}{|l|l|l|l|l|l|}
\hline & $\mathrm{N}$ & Minimum & Maximum & Mean & $\begin{array}{l}\text { Std. } \\
\text { Deviation }\end{array}$ \\
\hline Zscore(UDK) & 79 & -1.46568 & 2.18122 & .0000000 & 1.00000000 \\
\hline Zscore(PROFIT) & 79 & -2.39032 & 2.98927 & .0000000 & 1.00000000 \\
\hline Zscore(LEV) & 79 & -1.58577 & 2.79357 & .0000000 & 1.00000000 \\
\hline Zscore(CSR) & 79 & -2.09102 & 2.22049 & .0000000 & 1.00000000 \\
\hline $\begin{array}{l}\text { Valid N } \\
\text { listwise) }\end{array}$ & 79 & & & & \\
\hline
\end{tabular}


Tabel 4.4

Uji Normalitas residual

\begin{tabular}{|c|c|c|}
\hline \multicolumn{3}{|c|}{ One-Sample Kolmogorov-Smirnov Test } \\
\hline & & Unstandardized Residual \\
\hline \multicolumn{2}{|l|}{$\mathrm{N}$} & 79 \\
\hline \multirow{2}{*}{$\begin{array}{l}\text { Normal } \\
\text { Parameters }^{\mathrm{a}}\end{array}$} & Mean & .0000000 \\
\hline & Std. Deviation & .08846297 \\
\hline \multirow{3}{*}{\begin{tabular}{|l|} 
Most Extreme \\
Differences
\end{tabular}} & Absolute & .095 \\
\hline & Positive & .047 \\
\hline & Negative & -.095 \\
\hline \multicolumn{2}{|c|}{ Kolmogorov-Smirnov Z } & .844 \\
\hline \multicolumn{2}{|c|}{ Asymp. Sig. (2-tailed) } & .475 \\
\hline \multicolumn{2}{|c|}{ a. Test distribution is Normal. } & \\
\hline
\end{tabular}

Normal P.P Plot of Regression Standardized Residual

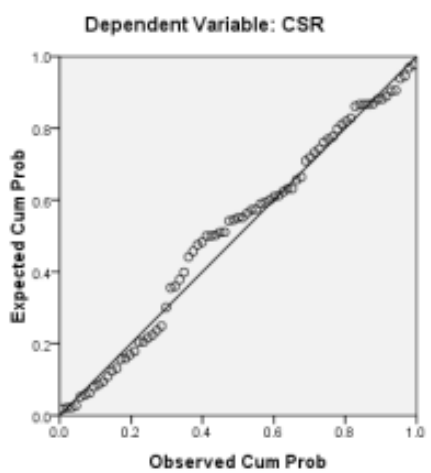

Tabel 4.5

Pengujian multikolinieritas

\begin{tabular}{|c|c|c|}
\hline \multirow{2}{*}{ Tolerance } & \multicolumn{2}{|c|}{ Collinearity Statistics } \\
\hline & VIF & \\
\hline UDK & .985 & 1.016 \\
\hline PROFIT & 1.888 & 1.126 \\
\hline LEV & .900 & 1.111 \\
\hline
\end{tabular}

Sumber : Data sekunder yang diolah 
Pengaruh Karakteristik Perusahaan terhadap Pengungkapan ....

Tabel 4.6

Uji Heteroskedastisitas

Scatterplot

Dependent Variable: CSR

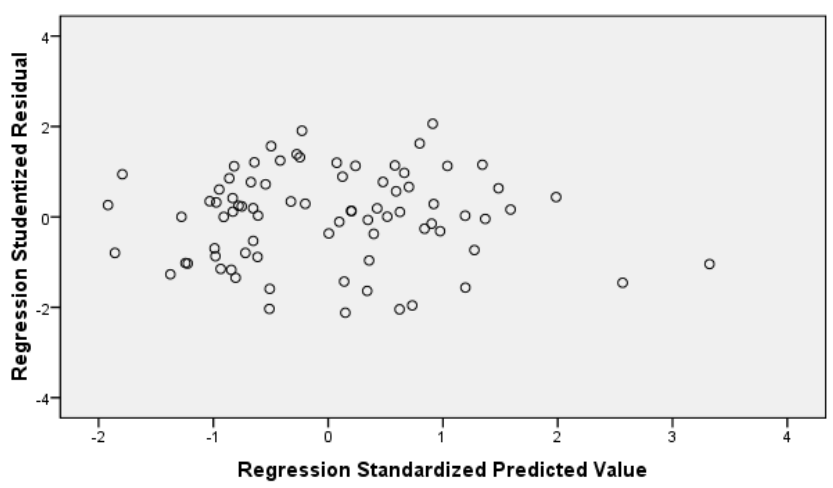

Coefficients $^{a}$

\begin{tabular}{|c|c|c|c|c|c|c|}
\hline \multirow{2}{*}{\multicolumn{2}{|c|}{ Model }} & \multicolumn{2}{|c|}{$\begin{array}{l}\text { Unstandardized } \\
\text { Coefficients }\end{array}$} & \multirow{2}{*}{\begin{tabular}{|l}
$\begin{array}{l}\text { Standardized } \\
\text { Coefficients }\end{array}$ \\
Beta \\
\end{tabular}} & \multirow[b]{2}{*}{$t$} & \multirow[b]{2}{*}{ Sig. } \\
\hline & & $B$ & Std. Error & & & \\
\hline \multirow[t]{4}{*}{1} & (Constant) & .097 & .021 & & 4.668 & .000 \\
\hline & UDK & -.004 & .003 & -.172 & -1.574 & .120 \\
\hline & PROFIT & -.002 & .001 & -.222 & -1.925 & .058 \\
\hline & LEV & .011 & .011 & .111 & .969 & .336 \\
\hline
\end{tabular}

Tabel 4.7

Pengujian autokorelasi Durbin Watson

Model Summary ${ }^{\mathrm{b}}$
\begin{tabular}{|l|l|l|l|l|l|}
\hline Model & $\mathrm{R}$ & R Square & $\begin{array}{l}\text { Adjusted R } \\
\text { Square }\end{array}$ & $\begin{array}{l}\text { Std. Error of } \\
\text { the Estimate }\end{array}$ & $\begin{array}{l}\text { Durbin- } \\
\text { Watson }\end{array}$ \\
\hline 1 & $.373^{\mathrm{a}}$ & .139 & .104 & .0902149 & 1.933 \\
\hline
\end{tabular}

a. Predictors: (Constant), LEV, UDK, PROFIT

b. Dependent Variable: CSR 
Tabel 4.8

Rekapitulasi hasil regresi

\begin{tabular}{|c|c|c|c|c|c|c|}
\hline & \multirow[t]{2}{*}{ Model } & \multicolumn{2}{|c|}{$\begin{array}{l}\text { Unstandardized } \\
\text { Coefficients }\end{array}$} & \multirow{2}{*}{\begin{tabular}{|c}
$\begin{array}{c}\text { Standardized } \\
\text { Coefficients }\end{array}$ \\
Beta
\end{tabular}} & \multirow{2}{*}{$\mathrm{t}$} & \multirow{2}{*}{ Sig } \\
\hline & & B & $\begin{array}{l}\text { Std. } \\
\text { Error }\end{array}$ & & & \\
\hline \multirow{4}{*}{1} & (Constant) & .136 & .037 & & 3.621 & .001 \\
\hline & UDK & .010 & .005 & .221 & 2.049 & .044 \\
\hline & PROFIT & -.0002 & .002 & -.015 & -.135 & .893 \\
\hline & LEV & .055 & .020 & .305 & 2.700 & .009 \\
\hline
\end{tabular}

a. Dependent Variable:

CSR

Tabel 4.9

Hasil Uji F

\begin{tabular}{|l|l|l|l|l|l|l|}
\hline \multicolumn{2}{|l|}{ Model } & $\begin{array}{l}\text { Sum of } \\
\text { Squares }\end{array}$ & $\mathrm{df}$ & Mean Square & F & Sig. \\
\hline \multirow{3}{*}{1} & Regression & .098 & 3 & .033 & 4.030 & $.010^{\mathrm{a}}$ \\
\cline { 2 - 7 } & Residual & .610 & 75 & .008 & & \\
\cline { 2 - 7 } & Total & .709 & 78 & & & \\
\hline
\end{tabular}

a. Predictors: (Constant), LEV, UDK, PROFIT

b. Dependent Variable: CSR

Tabel 4.10

Hasil Koefisien Determinasi

\begin{tabular}{|l|l|l|l|l|l|}
\hline Model & $R$ & R Square & $\begin{array}{l}\text { Adjusted R } \\
\text { Square }\end{array}$ & $\begin{array}{l}\text { Std. Error of } \\
\text { the Estimate }\end{array}$ & Durbin-Watson \\
\hline 1 & $.373^{\mathrm{a}}$ & .139 & .104 & .0902149 & 1.933 \\
\hline
\end{tabular}

a. Predictors: (Constant), LEV, UDK, PROFIT

b. Dependent Variable: CSR 
Pengaruh Karakteristik Perusahaan terhadap Pengungkapan ....

Item-Item Pengungkapan Tanggung Jawab Sosial Perusahaan

\begin{tabular}{|c|l|}
\hline \multicolumn{2}{|c|}{ KATEGORI } \\
\hline \multicolumn{1}{|c|}{ Lingkungan } \\
\hline 1 & $\begin{array}{l}\text { Pengendalian polusi kegiatan operasi; pengeluaran riset } \\
\text { dan pengembangan untuk pengurangan polusi }\end{array}$ \\
\hline 2 & $\begin{array}{l}\text { Pernyataan yang menunjukkan bahwa operasi } \\
\text { perusahaan tidak mengakibatkan polusi atau memenuhi } \\
\text { ketentuan hukum dan peraturan polusi }\end{array}$ \\
\hline 3 & $\begin{array}{l}\text { Pernyataan yang menujukkan bahwa polusi operasi } \\
\text { telah atau akan dikurangi }\end{array}$ \\
\hline 4 & $\begin{array}{l}\text { Pencegahan atau perbaikan kerusakan lingkungan akibat } \\
\text { pengolahan sumber alam, misalnya reklamasi daratan } \\
\text { atau reboisasi }\end{array}$ \\
\hline 5 & $\begin{array}{l}\text { Konservasi sumber alam, misalnya mendaur ulang kaca, } \\
\text { besi, minyak, air, dan kertas }\end{array}$ \\
\hline 6 & Penggunaan material daur ulang \\
\hline 7 & $\begin{array}{l}\text { Menerima penghargaan berkaitan dengan program } \\
\text { lingkungan }\end{array}$ \\
\hline 8 & Merancang fasilitas yang harmonis dengan lingkungan \\
\hline 9 & $\begin{array}{l}\text { Kontribusi dalam seni yang bertujuan untuk } \\
\text { memperindah lingkungan }\end{array}$ \\
\hline 10 & Kontribusi dalam pemugaran bangunan sejarah \\
\hline 11 & Pengolahan limbah \\
\hline 12 & $\begin{array}{l}\text { Mempelajari dampak lingkungan untuk memonitor } \\
\text { dampak lingkungan peusahaan }\end{array}$ \\
\hline 13 & Perlindungan terhadap lingkungan hidup \\
\hline & $\begin{array}{l}\text { Eengergi } \\
\text { operasi }\end{array}$ \\
\hline 2 & Memanfaatkan barang bekas untuk meproduksi energi \\
\hline 3 & $\begin{array}{l}\text { Mengungkapkan penghematan energi sebagai hasil } \\
\text { produk daur ulang }\end{array}$ \\
\hline 4 & $\begin{array}{l}\text { Membahas upaya perusahaan dalam mengurangi } \\
\text { konsumsi energi }\end{array}$ \\
\hline
\end{tabular}




\begin{tabular}{|c|l|}
\hline 5 & Pengungkapan peningkatan efisiensi energi dari produk \\
\hline 6 & $\begin{array}{l}\text { Riset yang mengarah pada peningkatan efisiensi energi } \\
\text { dari produk }\end{array}$ \\
\hline 7 & Mengungkapkan kebijakan energi perusahaan \\
\hline
\end{tabular}

\begin{tabular}{|c|l|}
\hline \multicolumn{2}{|c|}{ Kesehatan dan Keselamatan Tenaga Kerja } \\
\hline 1 & $\begin{array}{l}\text { Mengurangi polusi, iritasi, atau resiko dalam lingkungan } \\
\text { kerja }\end{array}$ \\
\hline 2 & $\begin{array}{l}\text { Mempromosikan keselamatan tenaga kerja dsn } \\
\text { kesehatan fisik atau mental }\end{array}$ \\
\hline 3 & Mengungkapkan statistik kecelakaan kerja \\
\hline 4 & $\begin{array}{l}\text { Menaati peraturan standard kesehatan dan keselamatan } \\
\text { kerja }\end{array}$ \\
\hline 5 & $\begin{array}{l}\text { Menerima penghargaan berkaitan dengan keselamatan } \\
\text { kerja }\end{array}$ \\
\hline 6 & Menetapkan suatu komite keselamatan kerja \\
\hline 7 & $\begin{array}{l}\text { Melaksanakan riset untuk meningkatkan keselamatan } \\
\text { kerja }\end{array}$ \\
\hline 8 & Mengungkapkan pelayanan kesehatan tenaga kerja \\
\hline & \multicolumn{1}{|c|}{ Lain-lain tentang Tenaga Kerja } \\
\hline 1 & $\begin{array}{l}\text { Perekrutan atau memanfaatkan tenaga kerja wanita/ } \\
\text { orang cacat }\end{array}$ \\
\hline 2 & $\begin{array}{l}\text { Mengungkapkan tujuan penggunaan tenaga kerja } \\
\text { wanita/orang cacat dalam tingkat manajerial }\end{array}$ \\
\hline 3 & $\begin{array}{l}\text { Mengungkapkan tujuan penggunaan tenaga kerja } \\
\text { wanita/orang cacat dalampekerjaan }\end{array}$ \\
\hline 4 & $\begin{array}{l}\text { Program untuk kemajuan tenaga kerja wanita/orang } \\
\text { cacat }\end{array}$ \\
\hline 5 & $\begin{array}{l}\text { Pelatihan tenaga kerja melalui program tertentu di } \\
\text { tempat kerja }\end{array}$ \\
\hline 6 & $\begin{array}{l}\text { Memberi bantuan keuangan pada tenaga kerja dalam } \\
\text { bidang pendidikan }\end{array}$ \\
\hline 7 & Mendirikan suatu pusat pelatihan tenaga kerja \\
\hline
\end{tabular}


Pengaruh Karakteristik Perusahaan terhadap Pengungkapan ....

\begin{tabular}{|c|l|}
\hline 8 & $\begin{array}{l}\text { Mengungkapkan bantuan atau bimbingan untuk tenaga } \\
\text { kerja yang dalam proses mengundurkan diri atau yang } \\
\text { telah membuat kesalahan }\end{array}$ \\
\hline 9 & $\begin{array}{l}\text { Mengungkapkan perencanaan kepemilikan rumah } \\
\text { karyawan }\end{array}$ \\
\hline 10 & Mengungkapkan fasilitas untuk aktivitas rekreasi \\
\hline 11 & Pengungkapan presentase gaji untuk pensiun \\
\hline 12 & $\begin{array}{l}\text { Mengungkapkan kebijakan penggajian dalam } \\
\text { perusahaan }\end{array}$ \\
\hline 13 & Mengungkapkan jumlah tenaga kerja dalam perusahaan \\
\hline 14 & Mengungkapkan tingkatan manajerial yang ada \\
\hline 15 & $\begin{array}{l}\text { Mengungkapkan disposisi staf - dimana staf } \\
\text { ditempatkan }\end{array}$ \\
\hline 16 & $\begin{array}{l}\text { Mengungkapkan jumlah staff, masa kerja dan kelompok } \\
\text { usia mereka }\end{array}$ \\
\hline 17 & $\begin{array}{l}\text { Mengungkapkan statisti tenaga kerja, misal penjualan } \\
\text { per tenaga kerja }\end{array}$ \\
\hline 18 & Mengungkapkan kualifikasi tenaga kerja yang direkrut \\
\hline 19 & $\begin{array}{l}\text { Mengungkapkan rencana kepemilikan saham oleh tenga } \\
\text { kerja }\end{array}$ \\
\hline 20 & Mengungkapkan rencana pembagian keuntungan lain \\
\hline 21 & $\begin{array}{l}\text { Mengungkapkan informasi hubungan manajemen } \\
\text { dengan tenaga kerja dalam meningkatkan kepuasan dan } \\
\text { motivasi kerja }\end{array}$ \\
\hline 22 & $\begin{array}{l}\text { Mengungkapkan informasi stabilitas pekerjaan tenaga } \\
\text { kerja dan masa depan perusahaan }\end{array}$ \\
\hline 23 & Membuat laporan tenaga kerja yang terpisah \\
\hline 24 & Melaporkan hubungan perusahaan dengan serikat buruh \\
\hline 25 & Melaporkan gangguan dan aksi tenaga kerja \\
\hline 26 & $\begin{array}{l}\text { Mengungkapkan informasi bagaimana aksi tenaga kerja } \\
\text { dinegosiasikan }\end{array}$ \\
\hline 27 & Peningkatan kondisi tekerja secara umum \\
\hline 28 & $\begin{array}{l}\text { Informasi re-organisasi perusahaan yang mempengaruhi } \\
\text { tenaga kerja }\end{array}$ \\
\hline 29 & Informasi dan statistik perputaran tenaga kerja \\
\hline
\end{tabular}




\begin{tabular}{|c|l|}
\hline \multicolumn{2}{|c|}{ Produk } \\
\hline 1 & $\begin{array}{l}\text { Pengungkapan informasi pengembangan produk } \\
\text { perusahaan, ternasuk pengemasannya }\end{array}$ \\
\hline 2 & Gambaran pengeluaran riset dan pengembangan produk \\
\hline 3 & $\begin{array}{l}\text { Pengungkapan informasi proyek riset perusahaan untuk } \\
\text { pengembangan produk }\end{array}$ \\
\hline 4 & $\begin{array}{l}\text { Pengungkapan bahwa produk memenuhi standard } \\
\text { keselamatan }\end{array}$ \\
\hline 5 & Membuat produk lebih aman untuk konsumen \\
\hline 6 & $\begin{array}{l}\text { Melaksanakan riset atas tingkat keselamatan produk } \\
\text { perusahaan }\end{array}$ \\
\hline 7 & $\begin{array}{l}\text { Pengungkapan peningkatan kebersihan/kesehatan dalam } \\
\text { pengolahan dan penyiapan produk }\end{array}$ \\
\hline 8 & $\begin{array}{l}\text { Pengungkapan informasi atas keselamatan produk } \\
\text { perusahaan }\end{array}$ \\
\hline 9 & $\begin{array}{l}\text { Pengungkapan informasi mutu produk yang diceminkan } \\
\text { dalam penerimaan penghargaan }\end{array}$ \\
\hline 10 & $\begin{array}{l}\text { Informasi yang dapat diverifikasi bahwa mutu produk } \\
\text { telah meningkat misal ISO 9000 }\end{array}$ \\
\hline
\end{tabular}

\begin{tabular}{|c|l|}
\hline \multicolumn{2}{|c|}{ Keterlibatan Masyarakat } \\
\hline 1 & $\begin{array}{l}\text { Sumbangan tunai, produk,pelayanan untuk mendukung } \\
\text { aktivitas masyarakat,pendidikan dan seni }\end{array}$ \\
\hline 2 & $\begin{array}{l}\text { Tenaga kerja paruh waktu (part-time employment) dari } \\
\text { mahasiswa atau pelajar }\end{array}$ \\
\hline 3 & Sebagai sponsor untuk proyek kesehatan masyarakat \\
\hline 4 & Membantu riset medis \\
\hline 5 & $\begin{array}{l}\text { Sebagai sponsor untuk konferensi pendidikan, seminar, } \\
\text { atau pameran seni }\end{array}$ \\
\hline 6 & Membiayai program beasiswa \\
\hline 7 & Membuka fasilitas perusahaan untuk masyarakat \\
\hline 8 & Mensponsori kampanye nasional \\
\hline 9 & Mendukung perkembangan industri lokal \\
\hline
\end{tabular}


Pengaruh Karakteristik Perusahaan terhadap Pengungkapan ....

\begin{tabular}{|c|l|}
\hline \multicolumn{2}{|c|}{ Umum } \\
\hline 1 & $\begin{array}{l}\text { Pengungkapan tujuan/kebijakan perusahaan secara } \\
\text { umum berkaitan dengan tanggung jawab sosial } \\
\text { perusahaan kepada masyarakat }\end{array}$ \\
\hline 2 & $\begin{array}{l}\text { Informasi berhubungan dengan tanggung jawab sosial } \\
\text { perusahaan selain yang disebutkan di atas }\end{array}$ \\
\hline
\end{tabular}

